\title{
A Rare Case: Gall Stone Induced Acute Pancreatitis with Normal Amylase and Lipase Levels
}

\author{
Arindam Mukherjee ${ }^{\circledR 1}$, Govind Madhav ${ }^{2}$, Ajay Tadha ${ }^{\circledR 3}$ \\ ${ }^{1}$ Consultant, Department of Surgery, Jaipur Golden Hospital, Rohini, Delhi, India, ${ }^{2}$ Senior Resident, Department of Surgery, Jaipur Golden Hospital, Rohini, Delhi, India, \\ ${ }^{3}$ Department of Surgery, Jaipur Golden Hospital, Rohini, Delhi, India.
}

\section{Abstract}

Acute pancreatitis (AP) is most commonly diagnosed by increased values of serum amylase and lipase. Acute pancreatitis where value of serum amylase and lipase is normal is very rare. This is a case of gall stone induced AP where levels of serum amylase and lipase are normal but the clinical suspicion and imaging are strongly confirming pancreatitis.

Keywords: Acute pancreatitis (AP), Gall stone, Amylase, Lipase

Corresponding Author: Govind Madhav, Senior Resident, Department of Surgery, Jaipur Golden Hospital, Rohini, Delhi, India. E-mail: govindmadhav3001@gmail.com

Received: 30 August 2020

Revised: 01 October 2020
Accepted: 09 October 2020

\section{Introduction}

Patient presenting with severe upper abdominal pain with high clinical suspicion of acute pancreatitis is confirmed with raised values of serum amylase and lipase. Although lipase estimation has better sensitivity and specificity than amylase, but it has been rarely reported to be present in normal values in confirmed cases of acute pancreatitis. ${ }^{[1-5]}$ The revised Atlanta classification of acute pancreatitis came in 2012, it states that two of the following three features are required to confirm a diagnosis of acute pancreatitis: pain abdomen where in there is an acute onset of a severe epigastric pain, which is persistent and radiating to the back; serum lipase or amylase values are three times higher than their normal; or evidence of inflammation of pancreas on CECT, MRI or trans-abdominal ultrasonography. ${ }^{[6]}$ There by increased level of amylase and lipase is not mandatory for diagnosing AP. Thus the diagnosis of AP should be considered in those cases also where the signs and symptoms of pancreatitis are present even if the values of amylase and lipase are normal, and should be evaluated by radiological aids.

We are reporting a case of 60 years lady with clinical picture of AP with normal values of serum amylase and lipase, but having signs of pancreatic inflammation on MRI.

\section{Case Report}

A 60 years lady came with complaints of severe pain abdomen and shortness of breath for 2 days. Pain was at epigastrium and around umbilicus, radiating to the back on the left. There was no history of similar pain in the past or history of alcohol addiction.

On general examination, she was conscious, but anxious. The patient was dehydrated. Her pulse rate was 98 beats / minute, feeble. Blood pressure was $90 / 60 \mathrm{~mm}$ of $\mathrm{Hg}$. Her respiratory rate was 28 / minute; regular with oxygen saturation of $92 \%$ on room oxygen. Rest of her general physical examination was unremarkable. Breath sounds were decreased in the midaxillary, and infra-scapular regions on the left side of the chest.

On per abdominal examination, all the quadrants were tense with maximum tenderness over epigastric region.

A clinical diagnosis of acute pancreatitis with left sided reactive pleural effusion with shock was arrived at, and her management was initiated on conservative line.

Her total leucocyte count was $15,100 / \mathrm{mm} .{ }^{[3]}$ The liver function and kidney function tests were normal. Serum alkaline phosphate was $153 \mathrm{IU} / 1$ and GGTP was $200 \mathrm{IU} / \mathrm{L}$. Her lipid profile and C-reactive protein was normal.

X-ray chest had blunting of left costo-phrenic angle. USG chest confirmed a bilateral pleural effusion. The USG of abdomen showed multiple mobile calculi in the lumen, with normal 
gall bladder wall and no free fluid collection. Pancreas was normal in the USG.

Serum amylase was found to be $69 \mathrm{U} / \mathrm{L}$ and serum lipase 16 $\mathrm{U} / \mathrm{L}$.

With strong clinical suspicion of pancreatitis, MRCP of the patient was done, which revealed bulky pancreas with diffuse oedematous signals with peripancreatic fat stranding and mild ill marginated fluid. The main pancreatic duct was not dilated [Figure-1]. There was minimal fluid in lesser sac [Figure-2]. The findings were suggestive of acute pancreatitis.

\section{Discussion}

Diagnosis of AP includes clinical features suggestive of pancreatitis with threefold increase in the values of lipase upto 48 hours of the initiation of symptoms and aided by radiological investigation if required. AP results in an augmented conversion of trypsinogen into trypsin; this causes pancreatic injury thereby illiciting an array of inflammatory response. ${ }^{[7]}$ Amylase and lipase are released from the acinar cells of the pancreas. Although serum trypsinogen-2 and trypsinogen activation peptide are two markers which are more specific to AP. They are detected early in case of AP. Because they are not commonly available and are expensive, thus are not used in regular practice for the diagnosis of AP. ${ }^{[5,8]}$ With the onset of AP, serum amylase values raises rapidly in 3 to 6 hours. Its half-life is of 10-12 hours and the values remain to be high for next 3 to 5 daysis excreted via kidney. ${ }^{[2]}$ The level of serum lipase also rises in 3 to 6 hours and reaches its highest value in 24 hours and stays raised for next one to two weeks. ${ }^{[4]}$ Unlike serum amylase, serum lipase is reabsorbed by the kidney tubules, thus its value remains elevated for a longer period thereby facilitating its detection for longer duration in subset of patients who present late. ${ }^{[9]}$ The elevated levels of serum amylase and lipase are important only for the detection of AP. Their raised levels neither determine the severity nor the prognosis of the disease. In this case the patient had indicating clinical features and imaging confirming AP, thereby meeting two out of three criteria, required as per the revised Atlanta classification for diagnosing AP were met, with persistent normal values of serum amylase and lipase.

Although many cases of AP with normal values of serum amylase are cited in literature, which can either due to failure of the inflamed pancreases to produce amylase, or coming of the amylase levels to normal levels prior to admission, ${ }^{[10,11]}$ specially in cases of acute on chronic pancreatitis and in hypertriglyceridemia-induced pancreatitis. ${ }^{[2]}$ Acute pancreatitis with normal levels of serum lipase is very uncommon.

In patients with strong clinical suspicion of AP where levels of serum amylase and lipase are normal, early use of imaging can be helpful in reaching the diagnosis and to rule out any other disease process. Ultrasound is not very useful in the diagnosis of AP but can help in identifying other conditions presenting with similar clinical features. CT scan and MRI/magnetic resonance cholangiopancreatography (MRCP) have high specificity and sensitivity in diagnosing acute pancreatitis. ${ }^{[12]}$

\section{Conclusion}

In conclusion, we suggest that in patients presenting with strong clinical features of AP even with normal values of serum amylase and lipase, the diagnosis of AP should be confirmed utilizing appropriate imaging modalities at the earliest to confirm the diagnosis.

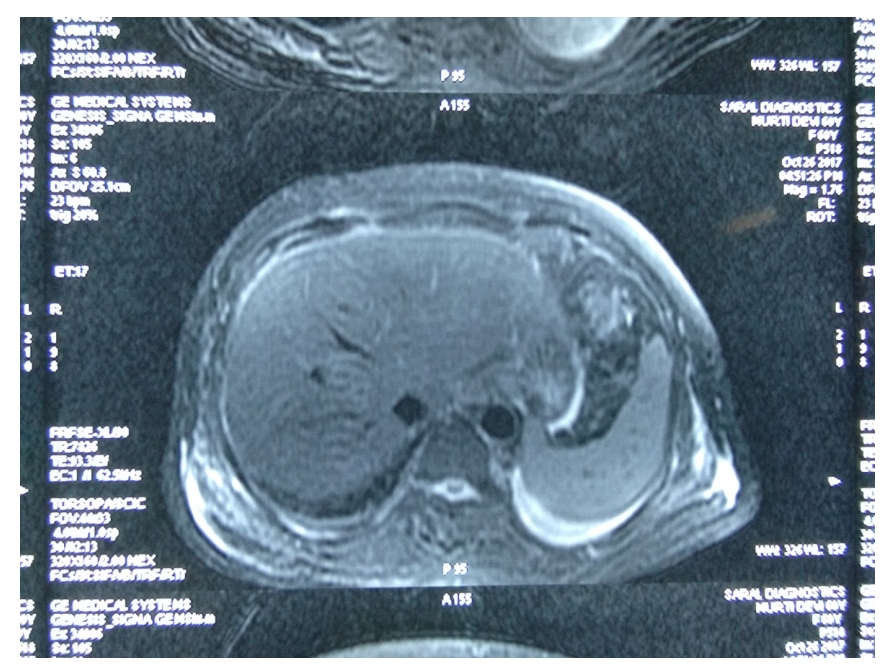

Figure 1: MRI abdomen axial T2 fat suppressed sequence shows left pleural effusion with fluid in lesser sac.

\section{References}

1. Vissers RJ, Abu-Laban RB, McHugh DF. Amylase and lipase in the emergency department evaluation of acute pancreatitis. J Emerg Med. 1999;17(6):1027-1037. Available from: https: //dx.doi.org/10.1016/s0736-4679(99)00136-5.

2. Clavien PA, Robert J, Meyer P, Borst F, Hauser H, Herrmann F, et al.. Acute Pancreatitis and Normoamylasemia; 1989. Available from: https://dx.doi.org/10.1097/00000658198911000-00008.

3. Neki NS, Shergill GS, Singh A, Rampal VK, Nizami S, Singh T. Acute pancreatitis with normal amylase and lipase levels. Postgrad Med Inst. 2017;31(2).

4. Cartier T, Sogni P, Perruche F, Meyniard O, Claessens YE, Dhainaut JF, et al. Normal lipase serum level in acute pancreatitis: a case report. Emerg Med J. 2006;23(9):701-703. Available from: https://dx.doi.org/10.1136/emj.2006.037655. 


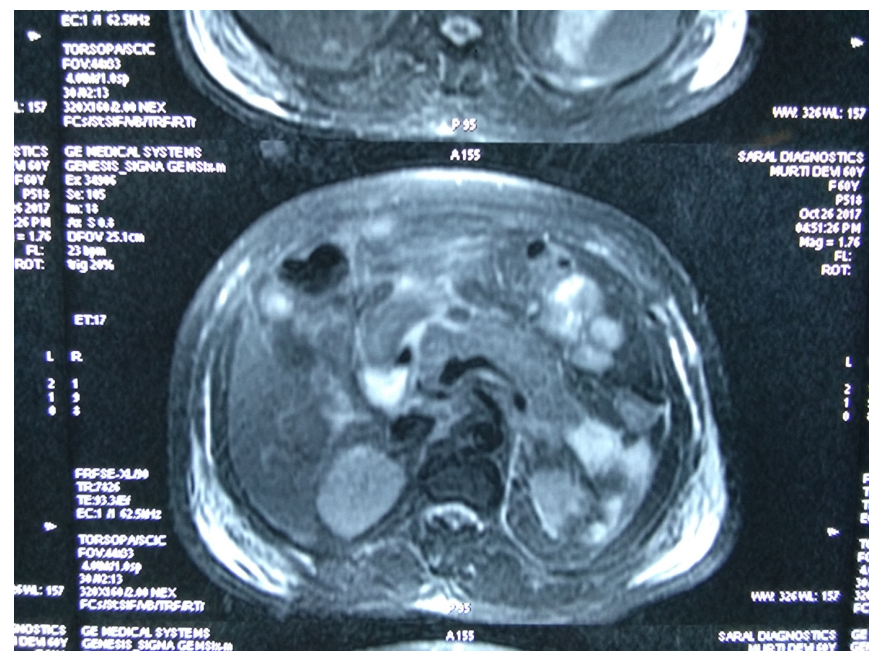

Figure 2: MRI abdomen axial T2 fat suppressed sequence shows diffusely bulky and oedematous pancreas withperipancreatic fat stranding. Fluid is also present in left perirenal space and along left posterior renal fascia.

5. Al-Bahrani AZ, Ammori BJ. Clinical laboratory assessment of acute pancreatitis. Clin Chim Acta. 2005;362(1-2):26-48. Available from: https://dx.doi.org/10.1016/j.ccen.2005.06.008.

6. Banks PA, Freeman ML. Practice Parameters Committee of the American College of Gastroenterology. Practice guidelines in acute pancreatitis. Am J Gastroenterol. 2006;101(10):2379400. Available from: https://doi.org/10.1111/j.1572-0241. 2006.00856.x.

7. Whitcomb DC. Value of genetic testing in the management of pancreatitis. Gut. 2004;53(11):1710-1717. Available from: https://dx.doi.org/10.1136/gut.2003.015511.

8. Kylänpää-Bäck ML, Kemppainen E, Puolakkainen P, Hedström J, Haapiainen R, Perhoniemi V, et al.. Reliable screening for acute pancreatitis with rapid urine trypsinogen-2 test strip; 2000. Available from: https://dx.doi.org/10.1046/j.1365-2168. 2000.01298.x.

9. Sternby B, O'Brien JF, Zinsmeister AR, DiMagno EP. What Is the Best Biochemical Test to Diagnose Acute Pancreatitis? A Prospective Clinical Study; 1996. Available from: https: //dx.doi.org/10.4065/71.12.1138.

10. Frank B, Gottlieb K. Amylase Normal, Lipase Elevated: Is It Pancreatitis?; 1999. Available from: https://dx.doi.org/10. 1111/j.1572-0241.1999.878_g.x.

11. Hiatt JR, Calabria RP, Passaro E, Wilson SE. The amylase profile: A discriminant in biliary and pancreatic disease; 1987. Available from: https://dx.doi.org/10.1016/00029610(87)90261-3.

12. Shah AM, Eddi R, Kothari ST, Maksoud C, Digiacomo WS, Baddoura W. Acute pancreatitis with normal serum lipase: a case series. J Pancreas. 2010;11(4):369-72.

Copyright: (C) the author(s), 2020. It is an open-access article distributed under the terms of the Creative Commons Attribution License (CC BY 4.0), which permits authors to retain ownership of the copyright for their content, and allow anyone to download, reuse, reprint, modify, distribute and/or copy the content as long as the original authors and source are cited.

How to cite this article: Mukherjee A, Madhav G, Tadha A. A Rare Case: Gall Stone Induced Acute Pancreatitis with Normal Amylase and Lipase Levels. Acad. J Surg. 2020;3(2):10-12.

DOI: dx.doi.org/10.47008/ajs/2020.3.2.3

Source of Support: Nil, Conflict of Interest: None declared. 